\title{
REPRESENTATION OF FEMALE EVIL AS AN INSTRUMENT FOR SATIRE ON POLITICAL VIOLENCE: MARTIN MCDONAGH'S THE LIEUTENANT OF INISHMORE1 İmren YELMIŞ²
}

\section{ABSTRACT}

Martin McDonagh's The Lieutenant of Inishmore has sometimes been severely criticised on the grounds that it is extremely violent and that McDonagh caricaturises Ireland, the Irish and the IRA and INLA terrorism in the play. Contrary to these arguments, however, this article aims to discuss that political violence applied by these non-legal organisations is satirised in the play albeit in a grotesque way. This satire is presented by means of use of female evil signified by Mairead. These discussions will further be elaborated by putting forward that Mairead, who embodies feminist ideas and ideals, and uses them inappropriately, not only represents violence in terrorist activities but also transgresses the gender roles designated by patriarchal discourse. Her masculine appearance, violent manners and her being involved in terrorist activities along with political violence show that behind terrorist activities there are also women besides men. Women terrorists who are represented by Mairead and think that they are dedicated to the "Irish cause" somehow enslave their so-called "beloved country", Ireland, in a vicious circle. This situation is satirised throughout the play.

Key Words: Martin McDonagh, The Lieutenant of Inishmore, IRA and INLA terrorism, feminist representation of female evil, satire on political violence

\section{POLITIK ŞIDDET ELEŞTİIISİ ARACI OLARAK ŞEYTANİ KADIN IMGESİ: MARTIN MCDONAGH'NIN THE LIEUTENANT OF INISHMORE (INISHMORE'UN YÜZBAŞISI OYUNU)}

ÖZ

Martin McDonagh'nın The Lieutenant of Inishmore (Inihmore'un Yüzbaşısı) adlı eseri, aşırı șiddet içerikli olduğu ve McDonagh'nın bu oyunda İrlanda'yı, Írlandalıları ve IRA ve INLA terörünü karikatürize

\footnotetext{
1 This article is a revised and expanded version of a part of the third chapter of my $\mathrm{PhD}$ Dissertation entitled “Satiric Representation of Violence in Martin McDonagh's The Beauty Queen of Leenane, A Skull in Connemara and The Lieutenant of Inishmore. 2 Dr. İmren Yelmiș, Hacettepe University, Faculty of Letters, Department of English Language and Literature, imrenyelmis@gmail.com
} 
ettiği gerekçesiyle bazen ciddi bir şekilde eleştirilmektedir. Bu eleştirilerin aksine, bu makalede, yasal olmayan bu kuruluşlar tarafindan uygulanan politik şiddetin grotesk bir şekilde de olsa eleştirildiği tartışılmaktadır. Bu eleştiri de, Mairead adlı karakter tarafindan temsil edilen şeytani kadın imgesinin kullanımıla yapılmaktadır. Bu çalışma, feminist fikir ve ideallerini temsil eden ve onları uygunsuzca kullanan Mairead'in terörist aktivitelerindeki şiddeti temsil ettiği ve onun, ataerkil söylem tarafindan belirlenen toplumsal cinsiyet rollerinin sınırlarını aştığı tartışılarak detaylandırılacaktır. Onun eril görünümü, şiddet içeren tavırları, terörist aktiviteleriyle ve politik şiddetle uğraşıyor olması, terörist aktivitelerde erkeklerin yanında kadınların da yer aldığını göstermektedir. Mairead tarafindan temsil edilen ve "İrlanda davası"na kendilerini adamış olduklarını düşünen kadın teröristler, bir bakıma "sevgili ülkeleri" Irlanda'yı bir kısır döngü içerisine hapsetmektedir. Bu durum da, oyun boyunca eleștirilmektedir.

Anahtar Sözcükler: Martin McDonagh, The Lieutenant of Inishmore (Inishmore'un Yüzbaşısı), IRA ve INLA terörü, şeytani kadın imgesinin feminist temsili, politik şiddet eleştirisi.

"We need these moral ordeals.

Theatre is only alive if it is kicking".

(John Peter, as cited

in Sierz, 2001: 96)

The beginning of Martin McDonagh's career as a playwright coincides with serious events witnessed in the 1990s. The media in the decade was full of news that reflected "war and killing: terrorist bombs, ethnic cleansing and most graves left indelible images on the public imagination" (Sierz, 2001: 206). All these wars and terrorist activities caused much psychological and physical pain in people's lives. They always resulted in injuries, traumas and deaths, including those of many innocents; that is to say, they also had many psychological and physical negative impacts upon many people who were not even directly involved in these activities.

On the other hand, there had been many protests against wars, and military and political violence as reflected in the streets, in

128 | Celal Bayar Üniversitesi Sosyal Bilimler Dergisi - Cilt: 14, Sayı: 3, Eylül 2016 
the media and in the field of literature. Especially in literature, various anti-violence voices could be heard in different types of genres, particularly drama. Reflective of the impact of violence observed in the decade, plays began to be used as instruments for many young playwrights to voice their protests and objection towards these events. Furthermore, the stages also turned into locales where violent acts were acted openly. Consequently, violent characters began to be seen very commonly on the English stage (Sierz, 2001: 207).

These violent events and characters were reflected, nonexceptionally, in Martin McDonagh's play, The Lieutenant of Inishmore, which was completed in 1996 but was first performed on 11 April 2001 by the Royal Shakespeare Company at The Other Place, Stratford-upon-Avon (Burke, 2006: 157). The play is about the Troubles, INLA and IRA, which is a republican and Catholic group notorious for political violence and whose central aim is to unite Northern Ireland with the Republic. The play, in McDonagh's words, "came from a position of what you might call pacifist rage [, and] it's a violent play that is wholeheartedly anti-violence" (as cited in O'Hagan, 24.03.2001). McDonagh also stresses that he has written the play with an aim: "The violence has a purpose ... otherwise there's nothing particularly interesting about shooting people on stage. If people who've had violence inflicted on them on either side of the Troubles see this play, I hope they'll see it as anti-violence" (as cited in Rees, 2006: 131).

An in-depth and analytical reading in the light of McDonagh's satiric aim will reveal significant details about The Lieutenant. As a satirical work written in the vein of in-yer-face theatre, the play portrays a full picture of a society which mirrors the tragedy experienced as a consequence of political terrorism. It is true that he reflects "disturbing instances of grotesque, verbal, emotional, psychological, physical, structural violence - reason enough for Aleks Sierz to consider McDonagh one of his chief witnesses for In-Yer-Face Theatre" (Middeke, 2010: 228). The aim behind all this violence is, in fact, to underline that McDonagh has "something urgent to say" (Sierz, 2001: 5), and, thus, he "deal[s] with disturbing subjects" such as IRA and INLA terrorism, murders, injuries and violence to "wak[e] up the audience" (Sierz, 2001: 5), to raise an awareness of the 
seriousness of terrorist activities, and to make the audience understand how it feels like to be exposed to political violence.

McDonagh displays his satire on the IRA and INLA terrorism through many different characters in The Lieutenant such as the ones who are directly involved in terrorist activities like Padraic, James, Christy, Brendan and Joey, and the ones who are innocent and indirectly has to be involved in the activities of the INLA members such as Davey and Donny. In this article, however, the only female character of the play, Mairead will be analysed in line with her tendency to be ruthless in issues in respect of INLA, IRA or Ireland. Generally, in the issues related to terrorism, women are considered to be at a secondary position, their significance in terrorist activities is ignored. In fact, women terrorists might be as dangerous as male ones. As Bloom puts forth, "[w] hen most people superficially picture the stereotypical terrorist, they usually think of a male, between the ages of 18 and 30, perhaps of Middle Eastern or Arabic descent. Few people immediately associate terrorism with women even though women have always been involved in terrorism and political violence" (2015: 41). In many literary works, too, violence is generally presented as a male conduct, as a part of masculinity. In this article, however, female evil will be concentrated upon to argue that McDonagh uses this along with the misrepresented way of feminist view of freedom and equality for women to emphasise terrorists' negligence and blatant disregard for human rights for the sake of their so-called "cause". It will also be discussed that, unlike the general criticism levelled at McDonagh's The Lieutenant stating that the play "is openly offensive to Irish republicans, animal rights advocates, and others" (Dean, 2002: 161), and that it might even cause trouble for the peace process (O'Hagan, 24.03.2001) in Northern Ireland, which was built after much effort in the 1990s, this article argues that McDonagh satirises these acts of violence no matter what the reasons behind them are. Through female evil, McDonagh, in the play, mainly focuses on and satirises the Troubles (the end of the 1960s-1998) experienced as a result of the serious conflict between the Catholics and Protestants on the Irish Island because of the political status of Northern Ireland, and "reflects the Irish issue as something still to be settled" (Middeke and Schnierer, 2010: xiii).

\section{Mairead as a Feminist Representation of Female Evil}

130 | Celal Bayar Üniversitesi Sosyal Bilimler Dergisi - Cilt: 14, Sayı: 3, Eylül 2016 
Mairead, as an evil woman, is an instrument for McDonagh's satire on political violence in The Lieutenant of Inishmore. Unlike the cliché representations of Irish women such as William Butler Yeats' and Lady Gregory's Cathleen ni Houlihan character, who is associated with the national identity of Ireland, McDonagh, by means of Mairead, who is involved in terrorist activities, demythologises the mythological, folkloric, "social and historical image of women, the one devised by the folk-imagination" (Ni Chuilleanain, 1985: 1). Mairead is depicted as a deviant and "mad" person (McDonagh, 2001: 18) for whom violence is already a routine pastime. She recklessly and thoughtlessly shoots with her rifle here and there, does not hesitate even a second before blinding the eyes of the cows as a socalled "political protest [...] against [...] meat trade" (McDonagh, 2001: 18), blinds Brendan, Joey and Christy while they are about to kill Padraic, "a second-lieutenant at the age of twenty-one" (McDonagh, 2001: 20), and she, in the end, kills her lover, Padraic, when she learns that he has killed her cat, Sir Roger. Her gradual engagement in terrorism, in a way, transforms her into a monstrous figure. Furthermore, her "madness", her mental disturbance might, in fact, represent a country decaying due to terrorist activities which have never totally ended for decades. In other words, the madness reflects how a country can be transformed into a hell and a person into a psychopath as a result of terrorism.

As a self-assertive woman, Mairead contributes to the discussion of political culture of Ireland in The Lieutenant. She is a politically motivated woman, a devoted rebel, and an activist who yearns for the unification of Northern Ireland with the Republic like her namesake Mairead Farrell, "a convicted bomber who led the evening rosary in Irish at Armagh" and was "gunned down in a Gibraltar street by the British SAS on 8 March 1988" (Scanlan, 1995: 162). Mairead's political motivation might be understood from the following rebellious and nationalistic songs and their lyrics that she continuously sings: "The Dying Rebel": "The last thing I met was a dying rebel. [...] Kneeling low I heard him say, God bless the cause for which I die" (McDonagh, 2001: 20); "The Patriot Game": "Come all ye young rebels and list while I sing. The love of one's land is a terrible thing. It banishes fear with the speed of a flame, and it makes us all a part of the patriot game" (McDonagh, 2001: 32). Later she sings as follows: "And now as I lie with my body all holed ... I think of the 
traitors who bargained and sold ... And I'm sorry my rifle has not done the same ... for the Quislings who sold out the patriot game" (McDonagh, 2001: 37). Besides, when she meets Padraic after five years, she introduces herself as "a part of the patriot game", and emphasises that she "was taught all [her] life cruel England's to blame" (McDonagh, 2001: 32). Her political motivation might also be understood from the name of her cat, Sir Roger, which was named after Sir Roger Casement, "the Irish diplomat and patriot" who "attempted to smuggle arms into Ireland from Germany for use in the Easter Rising against British Rule" in 1916 (Lonergan, 2012: 251), and from her decision to marry Padraic only when "Ireland is free!" (McDonagh, 2001: 61). As Gus Martin suggests, "[t]he perpetrators of violent acts uniformly maintain that they are freedom fighters (in the case of revolutionaries)" (2006: 5), and Mairead seems to be representative of these revolutionaries.

McDonagh presents Mairead as a girl who has independence of thought and behaviour again like Mairead Farrell, who was "an intelligent and charismatic figure [who] became something of a feminist icon, held to exemplify a questioning of masculine power, heroism and orthodoxy" (English, 2003: 257), and Mairead never accepts to be suppressed by anyone, male or female. Embodiment of feminist characteristics, Mairead is a person who tries to prove that women can be equal to men even in terms of power and leadership. Her desire to join one of the splinter groups of the IRA and later her declaration of herself as the "lieutenant" (McDonagh, 2001: 66) through which she is initiated into terrorist activities show that she tries to prove her freedom and power and that women "are just as dedicated [as the men] to the Cause" (Bloom, 2015: 51). Violent politics, in Harmon and Holmes-Eber's words, hence, "[becomes] a kind of social equalizer for women and men" (2014). As O'Connor argues, "[o]ne of the things related to the idea of liberation is equity, especially occupational equity. Women have to fight constantly for recognition they are equivalent to (or possibly better than) men" (2013). He goes on to emphasize that in order to prove themselves and to

avoid become double-losers by adding a criminal career to a boring occupational career[, the] women who turn to crime, therefore, don't tend to come from the ranks of losers. They come from the ranks of winners. They are what criminologists call "able"

132 | Celal Bayar Üniversitesi Sosyal Bilimler Dergisi - Cilt: 14, Sayı: 3, Eylül 2016 
criminals -- smart, proficient, versatile, and eager to learn. If their excitement can be channelled toward terrorism, it is entirely possible that women will become the more proficient terrorists. (2013)

Mairead seems to represent the women mentioned by O'Connor - the ones whose "excitement" and effort to prove their equality to men are "channelled toward terrorism" (2013), and who inflict serious and irremediable harm on people and society. Feminist characteristics reflected in Mairead seem to be used functionally by McDonagh to reflect the background of female terrorism in political violence.

In fact, McDonagh's first description of Mairead in the stage directions may be explained in line with the socially-constructed gender depictions determined for males. Unlike her brother Davey, who is said to have "girly hair" (McDonagh, 2001: 21), and, except for the two adjectives, "slim, pretty" (McDonagh, 2001: 17), she is portrayed completely as a male figure: "Mairead is a girl of sixteen or so, slim, pretty, with close-cropped hair, army trousers, white T-shirt, sunglasses. She carries an air rifle" (McDonagh, 2001: 17). Although in her later depiction she is described "in lipstick and a little make-up for once" (McDonagh, 2001: 32) to attract Padraic who is associated with patriotism and rebellion, she still resembles a boy as explained by Padraic himself: "From a distance I thought 'What's a boy doing sitting there with lipstick on?', then as I got closer I realised it was a lass, just with shocking hair" (McDonagh, 2001: 33). Moreover, in the last scene, after she decides to go to Northern Ireland together with Padraic, she gradually changes her appearance again to look beautiful to Padraic, and to be accepted by him as "a secondlieutenant" (McDonagh, 2001: 57): "Mairead has entered through the front door, wearing a pretty dress and carrying a rucksack and air rifle" (McDonagh, 2001: 56). Furthermore, when Mairead tries to save Padraic from the other INLA members, she blinds Brendan, Joey and Christy. The INLA members' conversation about their being shot by a girl is thought-provoking. When Christy asks whether the one who shot them is "a boy or [...] a girl", Brendan says: "It was a boy with lipstick", and Joey adds: "It was a girl with no boobs, sure" (McDonagh, 2001: 51). They cannot accept the fact that they are blinded by a woman who is actually expected to be feminine rather than masculine. Even Brendan feels ashamed of being blinded by a 
woman. He says: “Oh, don't let me be killed by a girl, Sweet Jesus! I'll never live it down" (McDonagh, 2001: 51). Later, "Padraic caresses her hair and cheek, impressed beyond words at her abilities with a gun" (McDonagh, 2001: 51). It is observed that Mairead uses her femininity only to attract Padraic, her role model with whom she shares a common cause: "an Ireland free" (McDonagh, 2001: 60). As it might also clearly be seen, unlike the generally accepted social roles for women, Mairead's representation in general (except for a few feminine characteristics presented to attract Padraic) is actually that of "the deviant woman as 'non-woman', or as masculine, unfeminine woman" (de Cataldo Neuberger and Valentini, 1996: 33). By deviating from the norms of patriarchy, she tries to prove that she can be as strong as a man, or even stronger than a man in Irish issues. As de Cataldo Neuberger and Valentini aptly put it, "women who engage in illegal activities considered traditionally the domain of men supposedly do so because they are, in essence, masculine. Women involved in politically deviant activities, the modern female terrorist in particular, have been portrayed as unisexed, unattractive and 'unnatural'" (de Cataldo Neuberger and Valentini, 1996: 33). In a similar strand, Mairead is "unnatural" due to her involvement in INLA terrorism. Moreover, she stubbornly does not care for the comments made about herself:

Padraic: When you get up close to you, you don't really look like a boy at all.

Mairead: Thank you.

Padraic: Just except for your hair.

Mairead: From you that's some kind of compliment, I suppose?

Padraic: Would you let your hair be growing out a tadeen, Mairead? Just to about here, now. Like Evie off The House of Elliot?

Mairead: Would you like me to?

Padraic: Aye.

Mairead: Well, me hair's staying the way it is and feck

Evie off The House of Elliot. (McDonagh, 2001: 58-59)

Considering the behaviours and appearance of Mairead, one may "speak of the deastheticisation of the female body" (de Lauretis, 1987: 146) as she does not accept the objectification of women by patriarchy, and as she wants to be accepted with her ideas rather than her feminine and attractive appearance. Padraic, on the other

134 | Celal Bayar Üniversitesi Sosyal Bilimler Dergisi - Cilt: 14, Sayı: 3, Eylül 2016 
hand, wants to have the power by means of commodifying the female body through "the male gaze". As Tyson underlines, generally [p] atriarchal power is also evident [...] in what many thinkers refer to as the male gaze: the man looks; the woman is looked at. And it is the one who looks who is in control, who holds the power to name things, the power to explain the world and so to rule the world. The one looked at - the woman-is merely an object to be seen. Thus, in a patriarchy, women are merely tokens, markers, commodities in a male economy. [...] In short, patriarchy is a man's world: men invent the rules of the game, they play it only with one another, and women are merely to be found among the prizes. (2006: 102)

Unlike Padraic's expectations, however, Mairead shapes her appearance and thoughts according to her political ideals rather than the social roles and norms constructed for women. With these characteristics, she challenges the concept of "patriarchal woman", in Tyson's words, "a woman who has internalised the norms and values of patriarchy, which can be defined, in short, as any culture that privileges men by promoting traditional gender roles" (2006: 85). Actually, "[t]raditional gender roles cast men as rational, strong, protective, and decisive; they cast women as emotional (irrational), weak, nurturing, and submissive", and "they still might exclude women from equal access to leadership and decision-making positions (in the family as well as in politics, academia, and the corporate world)" (2006: 85). The same case might be observed when Padraic does not want to accept Mairead into the INLA saying "[n]ot as long as I have any say in the INLA. It's for your own good I'm saying this, Mairead. Be staying home, now, and marry some nice fella. Let your hair grow out a tadeen and some fella's bound to be looking twice at you some day, and if you learn how to cook and sew too, sure, that'd double your chances. Maybe treble" (McDonagh, 2001: 36). In Mairead's self-created world, however, there is no place for these "traditional gender roles". She deconstructs discursive norms, and shows how a female body can be a site for a metaphorical battlefield in which she fights against the gender roles determined by the patriarchal norms, and, in this way, she can control her own body, which also shocks men around her. Mairead's rebellion against the 
patriarchal society through cross-dressing parallels her ideology dominated by her rebellious and independent thoughts, and might be considered as a reaction to the expectations of men. Mairead may be regarded as the symbol of "daring women who overstepped the boundaries of prescribed social roles" (Bitel, 1996: 214). She writes her own script in which she defies the representation of woman as defined by the patriarchal system, challenges wearing the apron in the kitchen as expected from her, and chooses to wear military trousers and to be a militant in a splinter terrorist group, which, in the end, paves the way for her to be "the lieutenant" of Inishmore (McDonagh, 2001: 66).

When she leaves home to found a splinter terrorist group, called Wee Thomas's Army, Mairead cannot promise her mother that she will not expose children to bombing events (McDonagh, 2001: 57), implying that she does not have mercy even on innocent people who are non-combatant while doing her "job", in other words, while bombing somewhere or trying to kill anti-IRA people. As a result, terrorism turns into a great threat for innocent people as well. The minimalistic conversation between the mother and daughter, Mairead, before the latter leaves her home to found a splinter terrorist group with "mad" Padraic, in fact, reveals many details about the condition of the country and its people, and the female evil's inner voice. This conversation is later reported to Davey by Mairead:

Davey: What did Mam say to you when you left?

Mairead: She said good luck and try not to go blowing up kids.

Davey: And what did you say?

Mairead: I said I'd try but I'd be making no promises.

Davey: And what did she say?

Mairead: She said so long as you try is the main thing.

Davey: I suppose it is. (McDonagh, 2001: 57)

In fact, indifference towards and the normalisation and naturalisation of the violent terrorist events are in question here. The mother's wish of good luck for Mairead in her terrorist activities and her condoning the death of innocent children indicate, in an American critic and historian, J. Bowyer Bell's terms, "an acceptable level of violence" (as cited in Scanlan, 1995: 172). As Lonergan emphasises, "McDonagh's target in The Lieutenant is not just Irish terrorism but also the compliant and complacent culture that makes

136 | Celal Bayar Üniversitesi Sosyal Bilimler Dergisi - Cilt: 14, Sayı: 3, Eylül 2016 
Irish terrorism possible" (2012: 74). Moreover, through Mairead, McDonagh shows that behind terrorist activities lie not only men but also women figures who are as much responsible for the death of many innocent people as men. In the name of the so-called big cause and through her "liberated mind and body", Mairead disregards humanity and human rights in general. Her mentality shaped by monstrous ideas and ideals may be clearly understood when she ignores the children and the grown-up innocents. In fact, since 1985, women terrorists "have killed hundreds of men, women, and children and their acts have maimed, blinded or crippled thousands more. Dozens more women have tried and failed, and allegedly hundreds are being trained for the future" (Bloom, 2015: 43). By means of Mairead, McDonagh, in a way, emphasises the significant role of women terrorists particularly in bombing events related to political terrorism. In order to emphasise Mairead's monstrosity and ruthless heart, he brings forth the "sensitive side" of a male terrorist, Padraic, who is reflected as "not only ruthless, but similarly sympathetic and kind-hearted as well. [...] [U]pon hearing of Wee Thomas's supposed ailment, [for example,] he begins "crying heavily" (14)" (Knox, 2013: 369-370). By exaggerating the monstrosity in Mairead and emphasising the sensitiveness of Padraic, McDonagh actually deconstructs the stereotypes of women as non-violent.

In The Lieutenant, violence shown as a direct result of terrorism is presented to the audience to illustrate the consequences of violent and extremist ideologies, and the violent side of politics. As Lonergan points out, the "play features an almost sickening number of references to specific events from the Troubles - and many victims of the IRA and INLA are alluded to" (2012: 82) in order to show how much psychological and physical damage they have caused. In Martin's words, "[m]ost people would agree that politically motivated planting of bombs in marketplaces, massacres of 'enemy' civilians ... are terrorist acts" (2006: 3), and these acts are observed openly in the play: There are allusions to an event related to Airey Neave, Shadow Northern Ireland Secretary, who died as a result of a car bomb installed by the INLA in 1979 while he was leaving the car park of the House of Commons (McDonagh, 2001: 29); the 1988 event in Belgium in which Richard Heakin, a British soldier, was 
killed by the IRA (McDonagh, 2001: 55), the 1990 IRA murder of two Australian tourists in the Netherlands (McDonagh, 2001: 55), a 1992 IRA event in which eight Protestant builders were killed since they were working in a job connected with a military base (McDonagh, 2001: 44), and to the IRA's bombing a chip shop on the Shankill Road in 1993, which resulted in the death of nine civilians (McDonagh, 2001: 13). These references to real terrorist attacks not only reflect the tragic ends of many innocent people but also make one understand the background of real violent and cruel world of the IRA and INLA terrorists. McDonagh, through The Lieutenant, seems "to spread the knowledge of what humans are capable of" (Sierz, 2001: 239), and to make the audience understand the psychology of the ones who really experience this violence. Moreover, through Mairead, who would be proud to be involved in any of these activities, McDonagh criticises the ones who would want to participate in such an organisation in the name of "free Ireland".

By means of all these violent actions taken by activists, McDonagh attacks "the sentimentality of the terrorist movement as a noble response to 'the love of one's land'" (Rees, 2006: 133). That is, McDonagh seems not to accept the activists' terrorism and violence as an excuse for defending their "beloved" land. Mairead, in whose behaviours and words there is explicit physical and verbal violence, is so blind that she is not aware of the anarchist behaviours she exhibits, and cannot recognise that she herself is a danger to Ireland, her so-called beloved country. In this respect, her blinding Christy, Brendan and Joey and the cows may be symbolic. This act of blinding and her being a sharpshooter and sharp-sighted might paradoxically stand for her blindness to the facts. She, like "mad" Padraic and the INLA members, thinks that she will be able to create a free Ireland through violence and anarchy. They, however, are never aware of whether this desire and the violent methods they use for it are building some positive outcomes or only destroying the country. In this sense, it may be pointed out that the idea of "home", which is represented by Padraic's and Donny's cottage in The Lieutenant is used symbolically and metaphorically as it may be considered as a microcosm of Ireland and the world, both of which are insecure and have turned into war zones. Even the home, which is described as "sweet" (McDonagh, 2001: 3) on "a framed piece of embroidery" (McDonagh, 2001: 3), is under threat, and the setting prepares "an environment which says very little to the audience in terms of

138 | Celal Bayar Üniversitesi Sosyal Bilimler Dergisi - Cilt: 14, Sayı: 3, Eylül 2016 
justifying terrorism" (Rees, 2006: 136). It is in this cottage that Mairead blinds the INLA members, Christy, Brendan and Joey - who are later killed by Padraic - because they try to kill her lover, Padraic. Again it is here that she kills her own lover Padraic when she learns that he has killed her dear cat, Sir Roger, which signifies Ireland and nationalism for her. The interesting question, as regards McDonagh's character depiction, is: "How can such people contribute to the national struggle?" (Parlak, 2012: 100), and the conclusion reached is that their merciless actions that cause a great deal of agony to everybody and their violence committed only for the sake of violence cannot be justified or legalised. In this respect, The Lieutenant illustrates overall lack of safety and may be regarded as a representative text of the concept of homo homini lupus, in other words, "man is a wolf to his fellow man". Moreover, the play, as Karadağ argues, is a criticism of the transformation of humanity into a monster in this century (2011: 48). Hence, the cottage in which emotions are silent and the terrifying sounds of the guns fill everywhere becomes functional in satirising the violent side of politics.

Mairead is also functional in terms of reflecting McDonagh's criticism on the conflicts, illogical behaviours and inconsistencies of terrorist groups such as the IRA and its splinter groups which emerged as a result of ideological clashes among themselves. Actually, in the 1990s INLA members had disputes among themselves. As Sanders explains, instead of laying emphasis on Irish integrity, they were in the foreground with their stress on questions of the division and disagreement observed within their own group members and their perpetually being involved in feuding (2012: 195). Furthermore, "[t]he strong personalities that the lack of structured recruitment policy allowed into the movement inevitably clashed and turned their guns on each other" (Sanders, 2012: 195). In the play, the idea of fragmentation in the terrorist groups is reflected through Padraic's already leaving the INLA, and Mairead's and his aim to found another splinter group whose name will be "Wee Thomas's Army" (McDonagh, 2001: 59), named after his "dead" cat. It might be put forth in relation to Mairead's dream of founding another splinter group with Padraic, who says "I've been thinking of forming a splinter group. A splinter group is the best kind of group to splinter from anyways. It shows you know your own mind" (McDonagh, 
2001: 14), that the characters cannot even manage to have a stable group ideology or target. Besides, at the end of the play, when Mairead kills Padraic when she learns that Padraic is the one who has killed her dear Sir Roger to which she gives a "national" meaning, she even announces herself to Davey and Donny as the lieutenant of the newly founded splinter group: "One of ye's chop up Padraic, the other be chopping the fella there with the cross in his gob. And don't be countermanding me orders, cos it's a fecking lieutenant ye're talking to now" (McDonagh, 2001: 66). So, she founds another splinter group whose leader is she herself.

Actually, Mairead's leadership also projects the fact about the presence of female militants in a leader position albeit in small numbers and their being "involved in all manner of insurgent and terror groups" since 1968 (Bloom, 2015: 41-42). As Harmon and Holmes-Eber claim, "[e]ven in the twenty-first century, many of us retain the sense that women are the gentler sex, the nurturers, and the protectors. But modern militancy is dangerously misunderstood unless the counterterrorism and intelligence communities confront the fact that females have been and are fighting in the ranks, and are even taking a leadership role in some groups" (2014). This leadership and Mairead's masculine and strong behaviours, actually, question the generally accepted notion that only male power is identified with the use of guns, power and fighting.

Moreover, Mairead's founding a splinter group also shows the political conflicts among splinter group members. In this sense, her founding another splinter group signifies the background and conflicts of the establishment of splinter groups. McDonagh's references to the fragmentation within the INLA may be alluding to this fact and may also be the reflection of McDonagh's harsh criticism and political message that these group members - who cannot restore peace and political and ideological unity among themselves and who cannot reach any agreement - cannot bring unity to Ireland and the Irish. On the contrary, they enlarge the distance among the members of the same group, and accordingly, they become more of a hindrance to the political development of the country than a help. Let alone exhibiting any logical attempt to "change" Ireland, they do not even take any reasonable step towards forming an alliance within themselves or sharing the ideals of fraternity. So, audiences are expected to question how these people can change Ireland into better with these fragmented ideas.

140 | Celal Bayar Üniversitesi Sosyal Bilimler Dergisi - Cilt: 14, Sayı: 3, Eylül 2016 
The play ends, in Davey's words, with "Four dead fellas, two dead cats" (McDonagh, 2001: 68) only because of personal reasons: because of the fact that Padraic thinks that his dear Wee Thomas is killed and, as a result, he kills Sir Roger, and later because Mairead sees that her lover, Padraic is about to be killed and because she learns that Padraic has killed her cat, Sir Roger. Upon learning this, Mairead "shoots Padraic in the head with both guns" (McDonagh, 2001: 65). Over the years, Mairead has come to equate Sir Roger with Ireland. She says: "tomorrow I'll be launching, when I've had a chance to think, about how Sir Roger came to end up in this house in the first place, and how half black with it". She later sings: "My only son was shot in Dublin, fighting for his country bold. He fought for Ireland and Ireland only. The harp and shamrock, green, white and gold" (McDonagh, 2001: 67). At this point, McDonagh, at first sight, may be thought to be trivialising Irish terrorism and Ireland through personal reasons and cats. However, he, through this apparent trivialisation and grotesque representation of terrorism, in a way, tries to emphasise the seriousness of terrorism, and shows that the personal is confused and intermingled with the political. The slogan used so commonly by feminists, "the personal is political" (Hanisch, 1969: 4), in this respect, is valid in The Lieutenant albeit in a reversed and misrepresented way.

At the end of the play, when Davey asks, "will it never end? Will it never fecking end?" Donny answers: "It fecking won't, d'you know!" (McDonagh, 2001: 67). Then, "[s]light pause. A black cat scrambles through the hole high in the wall stage left and stands or walks along the shelf there. Donny and Davey look at each other, then slowly turn and look at the cat" (McDonagh, 2001: 67). When, in the last scene, Wee Thomas, which is responsible for all the chaos, and which, surprisingly and shockingly, appears alive, comes to the cottage, the audience, just like Davey and Donny, might be shocked because, they understand that all the violence and chaos experienced by all the characters have been in vain as also approved and questioned by McDonagh's spokesperson, Davey: "So all this terror has been for absolutely nothing?" (McDonagh, 2001: 68). In this respect, "[a]s social commentary, [the play] is ... denouncing terrorism by demonstrating the repulsiveness and futility of its cruelty and destruction" (Anderson, 2008: 294). Hence, "the political seriousness of this line" (Rees, 2006: 138) should not be 
underestimated, and this line may be regarded as the summary of Martin McDonagh's message in the play: Political terrorism which does not solve anything brings the country nowhere; on the contrary, it makes the already bad conditions worse, and causes the country to become trapped in a vicious circle of unsolvable problems.

Within the light of all these arguments, it might be stated that through the female evil represented by Mairead in The Lieutenant, McDonagh reaches a striking critical point for the condition of Ireland. Considered in relation to the device of female evil, and McDonagh's emphasis on mainly two categories of terrorists: "common criminals motivated by personal reasons" and "ideologically motivated individuals who take action for political reasons, real or imagined" (de Cataldo Neuberger and Valentini, 1996: 65), The Lieutenant might be regarded as a call to all the countries in the world to avoid political violence. In fact, as Bloom puts forth, "[c]onsidered nurtures and not destroyers, [women] are often regarded as too 'soft' and vulnerable for terrorism" (2015: 44). Contrary to the generally accepted stereotypes for women, however,

[t]oday's insurgencies and small terrorist groups include numerous women; they may command, execute, plan, handle logistics, write or translate publications, prepare false travel documents, manage safe houses, reconnoitre in advance of attacks, or do the shooting or bomb placement. Women are full participants in contemporary terrorism, yet this is not adequately recognized in the analytic community. (Harmon and Holmes-Eber: 2014)

McDonagh, through the representation of female evil and women militants by Mairead, brings forth this fact. He also seems to suggest that when the language of communication is violence, and when serious problems in society like violence are ignored, the problem gets bigger, and people can be beneficial neither to themselves and the ones around nor to their own countries and humanity. Hence, he suggests a change for better in society. What Ian Rickson, the former Artistic Director at the Royal Court Theatre, points is, actually, indicative of the possibility of change that in-yerface theatre emphasises: "Since the Greeks, one of theatre's jobs is to take us into some of the darkest area of life so that we should leave the theatre crying out for change" (as cited in Sierz, 2001: 246). The play's target, hence, is to create political consciousness in the

142 | Celal Bayar Üniversitesi Sosyal Bilimler Dergisi - Cilt: 14, Sayı: 3, Eylül 2016 
audiences' minds and emphasise the possibility of a change for better contrary to the "belief" of activists "that it is necessary to resort to violence in order for change to take place" and that "the end justifies the casualties of terrorist action" (de Cataldo Neuberger and Valentini, 1996: 65-66). In The Lieutenant, it is implied that violence, no matter by whom it is applied - male or female -, prevents healthy communication between people and countries. Only through communication, understanding and respect one can solve problems and reach a compromise. It is possible that the term, "sweet home", paradoxically and ironically used at the beginning of the play to reflect the chaos observed in the Republic and Northern Ireland, might not be a dream when the violence is over. Only then would it be possible to mention Ireland as "the paradise of Emerald Isle".

\section{WORKS CITED}

ANDERSON, Monica Fay (2008), "The Lieutenant of Inishmore", Theatre Journal, 60 (2), pp. 294-98, (https://muse.jhu.edu/journals/theatre journal/v060/60.2.anderso n.html\# img04), (13.03.2013)

BITEL, Lisa M. (1996), Land of Women: Tales of Sex and Gender from Early Ireland, Cornell UP, Ithaca \& London.

BLOOM, Mia M. (2015), "The Changing Nature of Women in Extremism and Political Violence", (eds.) Cindy J. Smith, Marina Mazzini and Leif Villadsen, Freedom from Fear Magazine: Not in Our Name: The Lost Generation of Violent Extremists, 11, pp. 40-53, MaxPlack-Gesellshaft, Freiburg.

BURKE, Patrick (2006), "Like the Cat-astrophe of the Old Comedy': The Animal in The Lieutenant of Inishmore", (eds.) Lilian Chambers and Eamonn Jordan, The Theatre of Martin McDonagh: A World of Savage Stories, Carysfort, Dublin.

DEAN, Joan Fitzpatrick (2002), "The Lieutenant of Inishmore (review)", Theatre Journal, 54 (1), pp. 161-63, (https://muse.jhu.edu/), (13.03.2013)

de CATALDO Neuberger, Luisella and Tiziana Valentini (1996), Women and Terrorism, (trans.) Leo Michael Hughes, Palgrave Macmillan, New York.

de LAURETIS, Teresa (1987), Technologies of Gender: Essays on Theory, Film, and Fiction, Indiana UP, Bloomington \& Indianapolis. 
ELDRED, Laura (2007), "Martin McDonagh and the Contemporary Gothic", (ed.) Richard Rankin Russell, Martin McDonagh: A Casebook, pp. 111-130, Routledge, London and New York.

ENGLISH, Richard (2004), Armed Struggle: The History of the IRA, Pan Books, Basingstoke and Oxford.

HANISCH, Carol (1969), "The Personal is Political", (eds.) Shulamith Firestone and Anne Koedt, Notes from the Second Year, Radical Feminism, New York.

HARMON, Christopher C. and Paula HOLMES-EBER (2014), "Women in Terrorist Undergrounds", (ed.) Elizabeth Skinner, Global Ecco, 4 (4), (https://globalecco.org/from-the-editor44), (01.08.2016)

KARADAĞ, Özlem (2011), "İki Oyunda 'In-yer-face Tiyatrosu' ve Martin McDonagh: Leenane'in Güzellik Kraliçesi ve Inishmore'un Yüzbaşısı", Sahne: Tiyatro Opera ve Bale Dergisi, pp. 42-49.

KNOX, A. J. (2013), "Conflict, Carnage, and Cats: Toward a Comic Cú Chulainn in Martin McDonagh's The Lieutenant of Inishmore", Comparative Drama, 47 (3), pp. 367-392, (https://muse.jhu.edu/article/523652), (21.08.2015)

LONERGAN, Patrick (2012), The Theatre and Films of Martin McDonagh, Methuen, London.

MARTIN, Gus (2006), Understanding Terrorism: Challenges, Perspectives and Issues, $2^{\text {nd }}$ Edition, Sage, London.

McDONAGH, Martin (2001), The Lieutenant of Inishmore, Methuen, London.

MIDDEKE, Martin (2010), "Martin McDonagh", (eds.) Martin Middeke and Peter Paul Schniere, The Methuen Drama Guide to Contemporary Irish Playwrights, pp. 213-233, Methuen, London.

MIDDEKE, Martin and Peter Paul SCHNIERER (2010), "Introduction", (eds.) Martin Middeke and Peter Paul Schnierer, The Methuen Drama Guide to Contemporary Irish Playwrights, vii-xix, Methuen, Essex.

NI CHUILLEANAIN, Eilean (1985), "Introduction", (eds.) Eilean $\mathrm{Ni}$ Chuilleanain, Irish Women: Image and Achievement, pp. 111, Arlen House, Dublin.

O'CONNOR, T. (2013). "Female Terrorism", Mega Links in Criminal Justice, (http://www.drtomoconnor.com/3400/3400lect03a.htm), (13.07.2015)

144 | Celal Bayar Üniversitesi Sosyal Bilimler Dergisi - Cilt: 14, Sayı: 3, Eylül 2016 
O'HAGAN, Sean, "The Wild West", Guardian. 24 March 2001, (http://www.theguardian.com/lifeandstyle/2001/mar/24/weekend seanohagan), (15.06.2012)

PARLAK, Erdinç (2012), Martin McDonagh'nın Oyunlarında Siddet. Zafer Ofset Matbaacılık, Erzurum.

REES, Catherine (2006), "Lieutenant of Inishmore: Selling (out) to the English", (eds.) Lilian Chambers and Eamonn Jordan, The Theatre of Martin McDonagh: A World of Savage Stories, pp. 130-140, Carysfort, Dublin.

SANDERS, Andrew (2012), Inside the IRA: Dissident Republicans and the War for Legitimacy. CPI Group Ltd, Croydon.

SCANLAN, Margaret (1995), "An Acceptable Level of Violence: Women, Fiction, and Northern Ireland", (eds.) Theo D'haen and Jose Lanters, Troubled Histories, Troubled Fictions: Twentieth-Century Anglo-Irish Prose, 4, pp. 159-172, Rodopi, Amsterdam-Atlanta.

SIERZ, Aleks (2001), In-Yer-Face Theatre: British Drama Today, Faber and Faber, London.

TYSON, Lois (2006), Critical Theory Today: A User-friendly Guide, Routledge, New York and London. 